Darjeeling; four specimens.

This species is intermediate between R. latopalmata, Blgr. (=R. afghana, Gthr.), and $R$. formosa, Gthr. It is to the latter species that I referred the first two specimens which came under my notice (Cat. Batr. Ecaud. p. 70, R. formosa, specs. $c-d)$. With more material before me, which $\mathrm{I}$ owe to the kindness of Mr. W. T. Blanford, I have now no hesitation in establishing the above new species. The four closely allied forms which occur together at Darjeeling may be easily distinguished by means of the following synopsis :-

A. Third finger not longer than the distance between the nostril and the tympanum.

a. First finger extending a little beyond second; tympanum about half the diameter of the

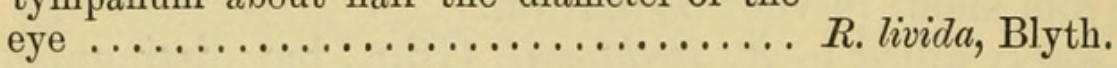

b. First finger not extending quite as far as second; tympanum not half the diameter of the eye $\ldots \ldots \ldots \ldots \ldots \ldots \ldots \ldots \ldots$ R. latopalmata, Blgr.

B. Third finger at least as long as the distance between the tip of the snout and the tympanum ; first finger much shorter than second.

a. Tibio-tarsal articulation reaching beyond the tip of the snout; tibia as long as the trunk

R. himalayana, Blgr.

$b$. Tibio-tarsal articulation reaching the tip of the snout; tibia considerably shorter than the

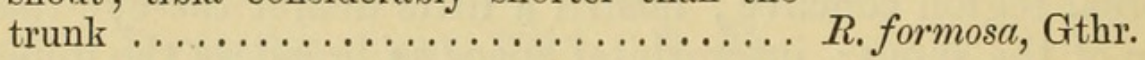

LXVII.-Description of a new Snake from Muscat, Arabia. By G. A. Boulenger.

In addition to specimens of Dermochelys coriacea, L., Zamenis diadema, Schleg., Rhagerrhis producta, Ptrs., Hydrophis cyanocincta, Daud., Echis carinata, Schn., and Echis colorata, Gthr., a collection recently presented to the British Museum by Surgeon-Major A. S. G. Jayakar, of Muscat, contains a new Eryx, which I have much pleasure in naming after its discoverer

\title{
Eryx Jayakari.
}

Snout much depressed, the nostril projecting and with trenchant edge; a loreal groove; nostril between three nasals, the upper of which is the largest; the rostral, the two upper nasals, and an internasal meet with their angles, the sutures forming an $\mathrm{X}$; upper head-scales small, in four longitudinal series between the eyes, which are very small, 
turned upwards, and surrounded by a circle of nine scales; eleven upper labials, third deepest and extending to the loreal groove; two large shields between the three following labials and the loreal groove, the second of which enters the eye ; fourteen lower labials. A mental groove. Scales smooth, in 39 longitudinal series. Ventrals about 180 ; subcaudals 20. Anal spurs well developed. Tail once and a half the length of the head, pointed, ending in a curved, claw-like, horny scute similar to the anal spurs. Greyish brown above, with whitish spots and numerous, rather irregular, dark brown cross bands; head dotted with dark brown; lower parts white.

Total length 40 centim.

A single specimen.

\section{MISCELLANEOUS.}

The Nest and Eggs of the Alligator (Alligator lucius, Cuv.). By Prof. Samuel F. Clarke, Williams College, Mass. U. S.

IT is somewhat remarkable that so promising a field of inquiry as that of reptilian embryology should have been so generally neglected; and it is certainly remarkable that almost nothing is known of the development of the Crocodilia or Loricata, the largest and most highly organized of the reptiles. The eggs and young alligators are such common objects in the shop windows in many of the Southern States that it appeared to be a simple matter to secure the eggs at the right time and in abundance. It proved, on the contrary, to be very difficult. I was assured by various hunters in Florida that each month from January to September inclusive was the only month in which the alligators lay their eggs, and this resulted in my having to make two journeys of over 2600 miles each.

At the time of my first visit, the first week in April, no eggs had been laid, and the ovaries of adult female alligators were full of eggs of all sizes up to 26 millim. in diameter. I returned to Florida on June 4, and found that I was still somewhat early, as the nests were then being built. With the aid of five experienced hunters I at last succeeded in finding, on the 9th of June, a nest evidently just eompleted in which there were twenty-nine eggs. The next day, at a point 40 miles further north, a second nest was found with thirty-one eggs.

There were many nests found, old and new, but only these two contained eggs.

The nests vary much in size, the largest being about $2 \frac{1}{2}$ metres in diameter at the base and 80 centim. high in the central part, the whole having the shape of a rounded cone; they are located generally on a slightly elevated place, which is higher by a metre, or slightly more, than the surrounding level, and covered with a thick 


\section{$2 \mathrm{BHL}$ Biodiversity Heritage Library}

Boulenger, George-Albert. 1888. "LXVII.- Description of a new snake from Muscat, Arabia." The Annals and magazine of natural history; zoology, botany, and geology 2, 508-509. https://doi.org/10.1080/00222938809487522.

View This Item Online: https://www.biodiversitylibrary.org/item/81046

DOI: https://doi.org/10.1080/00222938809487522

Permalink: https://www.biodiversitylibrary.org/partpdf/147972

\section{Holding Institution}

Smithsonian Libraries

\section{Sponsored by}

Smithsonian

\section{Copyright \& Reuse}

Copyright Status: Public domain. The BHL considers that this work is no longer under copyright protection.

This document was created from content at the Biodiversity Heritage Library, the world's largest open access digital library for biodiversity literature and archives. Visit BHL at https://www.biodiversitylibrary.org. 